\title{
Trypsin-like protease of Streptomyces exfoliatus SMF13, a potential agent in mycelial differentiation
}

\author{
In Seop Kim and Kye Joon Lee
}

Author for correspondence: Kye Joon Lee. Tel: + 822880 6705. Fax: +82 28829285.
e-mail: lkj12345@alliant.snu.ac.kr

Department of

Microbiology, College of

Natural Sciences, and

Research Centre for

Molecular Microbiology,

Seoul National University,

Seoul 151-742, Korea

\begin{abstract}
Streptomyces exfoliatus SMF13 sequentially produced leupeptin, leupeptininactivating enzyme (LIE) and trypsin-like protease (TLP). TLP was produced upon exhaustion of glucose. Autolysis of mycelium was accompanied by an increase in TLP activity. However, in three bld mutants isolated from S. exfoliatus SMF13 after UV-mutagenesis, mycelium autolysis did not occur, and neither LIE nor TLP was produced, although leupeptin was produced. Production of both LIE and TLP was restored in a spontaneous Spo revertant of a bld mutant. In contrast, two whi mutants sequentially produced leupeptin, LIE and TLP. The molecular mass of TLP produced during morphological differentiation was estimated to be $31.8 \mathrm{kDa}$ by SDS-PAGE. The N-terminal amino acid sequence was RVGGTXAAQGNFPFQQXLSM. TLP was competitively inhibited by leupeptin; the inhibition constant was $0.015 \mu \mathrm{M}$. TLP effectively hydrolysed the mycelial protein extract of S. exfoliatus SMF13, but the hydrolytic activity was inhibited by leupeptin. It was concluded that morphological differentiation and production of TLP are coordinately regulated, that TLP may function as an enzyme in the metabolism of mycelial proteins, and that the hydrolytic activity of TLP is regulated by autogenous leupeptin in S. exfoliatus SMF13.
\end{abstract}

Keywords: Streptomyces exfoliatus, trypsin-like protease, leupeptin, regulation, morphological differentiation

\section{INTRODUCTION}

Streptomycetes are Gram-positive bacteria with an unusual morphological complexity. The growth of Streptomyces on solid media progresses as a sequential formation of substrate mycelium and aerial hyphae (Wildermath, 1970). The aerial hyphae appear to grow, at least partially, by the utilization of degraded substrate mycelium (Mendez et al., 1985; Miguelez et al., 1994), because the aerial mycelium has little access to other sources of nourishment (Chater, 1984). Little has been learned of the mechanism providing nutrients for aerial mycelium formation.

Streptomycetes produce a variety of extracellular

Abbreviations: BAPNA, $\mathrm{N}$-benzoyl-arginine $p$-nitroanilide; BAEE, $\mathrm{N}$ benzoyl-L-arginine ethyl ester; LIE, leupeptin-inactivating enzyme; TLCK, $N$ - $\alpha$-p-tosyl-L-lysine chloromethyl ketone; TLP, trypsin-like protease.

The EMBL accession number for the sequence reported in this paper is P80420. proteases (Peczynska-Czoch \& Mordarski, 1988) as well as protease inhibitors (Aoyagi, 1989). The secretion of extracellular proteolytic enzymes in streptomycetes often temporally coincides with the onset of secondary metabolism or morphological differentiation (Ginther, 1979; Gibb \& Strohl, 1988; Bascaran et al., 1990).

We (Kim \& Lee, 1995) have shown that Streptomyces exfoliatus SMF13 sequentially produces leupeptin, leupeptin-inactivating enzyme (LIE) and trypsin-like protease (TLP). Production of leupeptin was closely associated with mycelial growth, but it was inactivated by LIE when mycelial growth reached stationary phase in submerged cultures, or just before aerial mycelium was formed on surface cultures. TLP activity started to increase when leupeptin was nearly inactivated. The production of TLP correlated with a decline in biomass of submerged cultures, or with aerial mycelium formation on surface cultures. The activity of TLP was specifically inhibited by leupeptin. Autolysis of mycelium after stationary phase in submerged cultures was apparently 
retarded by addition of leupeptin; furthermore, aerial mycelium formation on surface cultures was retarded by addition of leupeptin (Kim \& Lee, 1995).

Various types of mutants of Streptomyces altered in the life cycle have been isolated. One type of developmental mutant, designated bld due to its 'bald' phenotype, is defective in aerial mycelium formation, and is subsequently impaired in the formation of spores (Champness, 1988). Another type of developmental mutant, designated $w b i$, produces white aerial mycelium but fails to form spores (Chater, 1984). Some bld mutants of Streptomyces are pleiotropically blocked in the biosynthesis of antibiotics and pigments (Chater, 1984; Martin \& Demain, 1980).

To elucidate the biological roles of TLP during morphological differentiation of $S$. exfoliatus SMF13, we isolated bld mutants and whi mutants and characterized their TLP production. We also purified TLP from the culture broth and determined its enzymic and other biochemical properties.

\section{METHODS}

Micro-organisms and strain maintenance. The parent microorganism was S. exfoliatus SMF13 (Kim et al., 1993; Kim \& Lee, 1995). Mutants were obtained by irradiating spores of $S$. exfoliatus SMF13 with UV light (254 nm) to give survival ratios of $0 \cdot 1-1 \%$. The irradiated spores were then plated on stock culture medium and incubated for $7 \mathrm{~d}$ at $28^{\circ} \mathrm{C}$. Colonies were visually screened for $b l d$ and whi mutants (Hopwood $e t$ al., 1985). As candidates, flat colonies lacking aerial mycelium formation and fluffy whitish colonies lacking spore formation were subcultured three times. Three stable bld mutants (SMF13B1, SMF13B2 and SMF13B3) and two stable whi mutants (SMF13W1 and SMF13W2) were finally picked. A spontaneous $\mathrm{Spo}^{+}$revertant (SMF13R1) to the wild-type phenotype was obtained from bld mutant SMF13B1 after storage for several weeks at $4{ }^{\circ} \mathrm{C}$. Strains were transferred to slopes of stock culture medium each month, and stored at $4{ }^{\circ} \mathrm{C}$.

Media and culture conditions. Stock culture medium (Bennett medium) consisted of $(\%, w / v)$ : glucose, 1 ; casein hydrolysate, $0 \cdot 2$; yeast extract, $0 \cdot 1$; beef extract, $0 \cdot 1$; and agar, $1 \cdot 8$. Seed culture medium consisted of $(\%, \mathrm{w} / \mathrm{v})$ : glucose, 3.0 ; soytone, $1 \cdot 8$; peptone, 0.3 ; and $\mathrm{CaCO}_{3}, 0.4$. The main culture medium (GCPS medium) consisted of $(\%, \mathrm{w} / \mathrm{v})$ : glucose, 0.5 ; sodium caseinate, $1 ; \mathrm{KH}_{2} \mathrm{PO}_{4}, 0.025 ; \mathrm{K}_{2} \mathrm{HPO}_{4}, 0.085 ; \mathrm{MgSO}_{4} .7 \mathrm{H}_{2} \mathrm{O}$, $0.03 ; \mathrm{NaCl}, 0.03 ; \mathrm{FeSO}_{4} .7 \mathrm{H}_{2} \mathrm{O}, 0.001 ; \mathrm{CuSO}_{4} .5 \mathrm{H}_{2} \mathrm{O}, 0.001$; $\mathrm{CaCl}_{2} .2 \mathrm{H}_{2} \mathrm{O}, 0.001$; and $\mathrm{MnCl}_{2} \cdot 4 \mathrm{H}_{2} \mathrm{O}, 0.0003$. The phosphate and salts were separately sterilized by filtration $(0.2 \mu \mathrm{m}$, Millipore membrane). For surface culture, about $10^{3}$ spores were inoculated evenly on GCPS agar medium, or spores from stock culture medium were transferred with sterile toothpicks to GCPS agar medium containing increasing concentrations of glucose, and incubated at $28^{\circ} \mathrm{C}$. For submerged batch cultures, $50 \mathrm{ml}$ seed culture medium in a $500 \mathrm{ml}$ baffled flask was inoculated with a spore suspension to give $10^{6}$ spores $\mathrm{ml}^{-1}$ and incubated at $28^{\circ} \mathrm{C}$ for $36 \mathrm{~h}$ on a rotary shaker $(200$ r.p.m. $)$. The seed culture was used to inoculate $(5 \%, v / v) 31$ of the GCPS medium contained in a jar fermenter ( $5 \mathrm{l}$; Korea Fermentor) maintained at $28^{\circ} \mathrm{C}$; the initial $\mathrm{pH}$ was adjusted to $7 \cdot 0$. Agitation and aeration were 200 r.p.m. and $1 \mathrm{v} \mathrm{v}^{-1} \mathrm{~min}^{-1}$, respectively.

Scanning electron microscopy. Colonies developed on agar medium were fixed using the following procedures. Phosphate- buffered glutaraldehyde solution $(8 \%, \mathrm{v} / \mathrm{v} ; \mathrm{pH} 7 \cdot 4)$ was poured into holes punched around colonies (Millonig, 1961). Plates were left for $24 \mathrm{~h}$ at $4{ }^{\circ} \mathrm{C}$; colonies were cut out to the minimal size from the agar medium and then dried in a sealed plastic box under $\mathrm{P}_{2} \mathrm{O}_{5}$ at $4{ }^{\circ} \mathrm{C}$. Dried colonies were gold-coated with a Polaron SC502 sputter coater (Fisons) at $15 \mathrm{~mA}$ for $1 \mathrm{~min}$ under vacuum. The morphology of colonies was observed with a Stereoscan 260 scanning electron microscope (Cambridge).

Analysis of growth, glucose and protein. Mycelium from submerged cultures was harvested aseptically by centrifugation at $12000 \mathrm{~g}$ for $15 \mathrm{~min}$, washed twice with physiological saline solution and once with distilled water, then collected by vacuum filtration (Whatman filter paper GF/C) and dried at $80^{\circ} \mathrm{C}$ for $24 \mathrm{~h}$. The concentration of glucose was measured with dinitrosalicylic acid (Miller, 1959). Protein concentrations were determined by dye binding (Bradford, 1976); bovine serum albumin was used as the standard.

Assay of TLP, leupeptin and LIE. Broth of submerged cultures was centrifuged at $10000 \mathrm{~g}$ for $10 \mathrm{~min}$ and the activities of TLP, leupeptin and LIE in the supernatant were measured. An agar plug $(5 \times 5 \mathrm{~cm})$ containing a lawn of mycelium was removed from the centre of each plate, or 50 agar plugs (diameter $1.2 \mathrm{~cm}$ ) containing a colony were removed from each plate, homogenized in $10 \mathrm{ml}$ Tris/ $\mathrm{HCl}$ buffer $(0.1 \mathrm{M}, \mathrm{pH} 7.5)$ and centrifuged (10000 $\mathrm{g}$ for $10 \mathrm{~min})$. The activities of TLP, leupeptin and LIE in the supernatant were measured.

TLP activity was estimated by measuring the amount of $p$-nitroanilide liberated from the $N$-benzoyl-arginine $p$ nitroanilide (BAPNA). Enzyme reactions were carried out with $200 \mu \mathrm{mol}$ BAPNA at $35^{\circ} \mathrm{C}$ and $\mathrm{pH} 7 \cdot 5$ (Tris/ $\mathrm{HCl}$ buffer, $0 \cdot 1 \mathrm{M}$ ). Activity was calculated from the linear part of the curve, using $\varepsilon_{405}=9620 \mathrm{~mol}^{-1} \mathrm{~cm}^{-1}$. One unit of TLP activity was defined as the amount of enzyme needed to produce $1 \mu \mathrm{mol} p$ nitroanilide $\min ^{-1}$ (Sarath et al., 1989).

The activities of protease inhibitors were calculated as percentage inhibition $=100\{(A-B) / A\}$, where $A$ is the protease activity without the inhibitor and $B$ is the protease activity with the inhibitor (Aoyagi et al., 1969). The concentration of leupeptin in culture broth was calculated from a standard curve prepared with authentic leupeptin and $80 \mu \mathrm{g}$ papain as the target protease (Kim \& Lee, 1995).

The activity of LIE was determined as follows. Mycelium-free culture broth $(1.0 \mathrm{ml})$ was preincubated with $50 \mu \mathrm{g}$ leupeptin at $4{ }^{\circ} \mathrm{C}$ and $\mathrm{pH} 7.5$ (Tris/ $\mathrm{HCl}$ buffer, $0.1 \mathrm{M}$ ) for $10 \mathrm{~min}$ to compensate for the possible interaction between leupeptin and TLP. The preincubated reaction mixture was incubated for $10 \mathrm{~min}$ at $35^{\circ} \mathrm{C}$, then heated for $5 \mathrm{~min}$ at $80^{\circ} \mathrm{C}$ for complete inactivation of any protease and LIE in the reaction mixture. The remaining activity of leupeptin was assayed $(A)$. In parallel, the preincubated reaction mixture was heated at $80^{\circ} \mathrm{C}$ for $5 \mathrm{~min}$ to completely inactivate $\mathrm{LIE}$, then incubated at $35^{\circ} \mathrm{C}$ for $10 \mathrm{~min}$. The remaining activity of leupeptin was assayed $(B)$. The difference between $A$ and $B$ was defined as the leupeptininactivating activity. One unit of LIE was defined as the amount of enzyme needed for inactivation of $10 \mu \mathrm{g}$ leupeptin $\mathrm{min}^{-1}$ (Kim \& Lee, 1995).

Purification of trypsin-like protease. When TLP activity reached its maximum in a batch culture, the broth was harvested by centrifugation ( $12000 \mathrm{~g}$ for $15 \mathrm{~min}$ ). TLP was purified from the cell-free broth by the following procedures at $4{ }^{\circ} \mathrm{C}$. Fractions from the $45-60 \%$ ammonium sulfate saturation range were dissolved in distilled water and desalted by ultrafiltration. The desalted solution was adjusted to $\mathrm{pH} 3.6$ with citrate buffer and kept for $30 \mathrm{~min}$. After centrifugation for $20 \mathrm{~min}$ at $20000 \mathrm{~g}$, the 
pellet was discarded. The supernatant solution was desalted by ultrafiltration in $0.05 \mathrm{M}$ Tris/ $\mathrm{HCl}$ buffer $(\mathrm{pH} \mathrm{7.5)}$. The soluble retentate was applied to a column of DEAE-Sephadex A-50 $(2.8 \times 22 \mathrm{~cm})$ equilibrated with $0.05 \mathrm{M}$ Tris $/ \mathrm{HCl}$ buffer $(\mathrm{pH} 7 \cdot 5)$, and eluted with a linear gradient of $\mathrm{NaCl}(0-1 \mathrm{M})$ in the same buffer. The active fraction was not retained by the resin, and was eluted with the Tris/ $\mathrm{HCl}$ buffer. It was concentrated by ultrafiltration in $0.005 \mathrm{M} \mathrm{Na}$-phosphate buffer $(\mathrm{pH} \mathrm{6.8)}$ and applied to a column of hydroxyapatite $(1.5 \times 18 \mathrm{~cm})$ equilibrated with $0.005 \mathrm{M} \mathrm{Na}$-phosphate buffer ( $\mathrm{pH}$ 6.8). After the column had been washed with $0.005 \mathrm{M} \mathrm{MgCl}_{2}$, the active fraction was eluted with $1 \mathrm{M} \mathrm{MgCl} 2$. It was concentrated and desalted by ultrafiltration in $0.05 \mathrm{M} \mathrm{Na}$-citrate buffer $(\mathrm{pH} \mathrm{4.0)}$, then applied to a column of CM-Sephadex $(2.8 \times 22 \mathrm{~cm})$ equilibrated with $0.05 \mathrm{M} \mathrm{Na}$-citrate buffer $(\mathrm{pH} \mathrm{4.0})$. The column was washed with 3 bed volumes of the same buffer, and TLP was then eluted with a linear gradient of $\mathrm{NaCl}(0-1 \mathrm{M})$ in the same buffer. TLP was collected in fractions containing about $0.5 \mathrm{M} \mathrm{NaCl}$.

Molecular mass determination and substrate gel electrophoresis. The molecular mass of the purified TLP was estimated by SDS-PAGE (Laemmli, 1970); the concentration of the running gel was $12 \%(\mathrm{w} / \mathrm{v})$ and that of the stacking gel was $5 \%$ $(\mathrm{w} / \mathrm{v})$. After electrophoresis, the gel was stained with Coomassie Blue.

TLP activity was visualized in polyacrylamide gels by incorporating $0.1 \%$ gelatin in a $10 \%(\mathrm{w} / \mathrm{v})$ SDS-PAGE gel. TLP in the sample buffer was not boiled before being applied to the gel.

$\mathrm{N}$-terminal amino acid sequencing. The $\mathrm{N}$-terminal amino acids of TLP were sequenced by a modified phenylthiohydantoin method (Matsudaira, 1987). The similarity of the $\mathrm{N}$-terminal amino acid sequence of TLP to other proteins was determined from the EMBL database using Clustal V software for multiple sequence alignment.

Substrate specificity and synthetic substrate hydrolysis. Hydrolytic activity for bovine albumin (Sigma), egg albumin (Sigma), Hammarsten casein (Merck), collagen (Sigma), elastin (Sigma), haemoglobin (Sigma) and lysozyme (Sigma) was estimated by measuring the concentration of tyrosine liberated from the substrate protein after $15 \mathrm{~min}$ reaction at $35^{\circ} \mathrm{C}$ and $\mathrm{pH} 7.5$ (Tris/ $\mathrm{HCl}$ buffer, $0.1 \mathrm{M}$ ). One unit of hydrolytic activity was defined as the amount of enzyme needed to produce $1 \mu \mathrm{g}$ tyrosine equivalent $\mathrm{min}^{-1}$ (Narahashi, 1970).

The kinetic parameters for hydrolysis of aminoacyl $p$ nitroanilides were measured under the optimum reaction conditions; concentrations of the aminoacyl $p$-nitroanilides ranged from $2 \cdot 5$ to $1000 \mu \mathrm{M}$ (Sarath et al., 1989).

Esterase activity of TLP was estimated by measuring the hydrolysis of $N$-benzoyl-L-arginine ethyl ester (BAEE). Hydrolysis of BAEE was monitored at $253 \mathrm{~nm}$ under the same conditions as used for measuring BAPNA hydrolysis. Activity was calculated from the linear part of the curve, using $\varepsilon_{253}=1150 \mathrm{~mol}^{-1} \mathrm{~cm}^{-1}$ (Sarath et al., 1989).

Degradation of mycelium protein. The mycelium harvested from the decline phase culture broth of $S$. exfoliatus SMF13 was washed three times with Tris/ $\mathrm{HCl}$ buffer $(\mathrm{pH} 7 \cdot 5,0.1 \mathrm{M})$, disrupted by sonication $(100 \mathrm{~W}, 5 \mathrm{~min})$ at $4{ }^{\circ} \mathrm{C}$, then centrifuged at $20000 \mathrm{~g}$ for $30 \mathrm{~min}$. The supernatant was used as the mycelium protein extract. TLP $(5 \mu \mathrm{g})$ dissolved in $200 \mu \mathrm{l}$ Tris $/ \mathrm{HCl}$ buffer $\left(\mathrm{pH} 7 \cdot 5,0 \cdot 1 \mathrm{M}\right.$ ) was preincubated at $35^{\circ} \mathrm{C}$ for $5 \mathrm{~min}$ with or without $10 \mu \mathrm{g}$ leupeptin. Then $2.8 \mathrm{mg}$ mycelium protein dissolved in $500 \mu \mathrm{l}$ Tris/ $\mathrm{HCl}$ buffer was added, and the reaction mixture was incubated at $35^{\circ} \mathrm{C}$. The hydrolysis of mycelium proteins was measured by SDS-PAGE as a function of time.

Analysis of fermentation kinetic parameters. Specific growth rate $(\mu)$, specific mycelium degradation rate $\left(k_{\mathrm{d}}\right)$, specific glucose uptake rate $\left(q_{\mathrm{s}}\right)$, specific leupeptin production rate $\left(q_{\mathrm{pt} t}\right)$ and specific LIE production rate $\left(q_{\mathrm{LIE}}\right)$ in batch cultures were analysed as follows (Pirt, 1975):

$\mu=\ln \left(x_{2} / x_{1}\right) /\left(t_{2}-t_{1}\right)$

and

$k_{\mathrm{d}}=-\ln \left(x_{2} / x_{1}\right) /\left(t_{2}-t_{1}\right)$,

where $x$ and $t$ are dry cell weight $\left(\mathrm{gl}^{-1}\right)$ and time (h), respectively;

$q_{\mathrm{s}}=(\mathrm{d} s / \mathrm{d} t) / x$,

where $\mathrm{d} s / \mathrm{d} t$ are changes in concentration of glucose during infinitesimal time $\left(\mathrm{g} \mathrm{l}^{-1} \mathrm{~h}^{-1}\right)$;

$q_{\mathrm{lpt}}=\left(\mathrm{d}_{\mathrm{lpt}} / \mathrm{d} t\right) / x$,

where $d_{1 p t} / d t$ is the increase in the concentration of leupeptin during infinitesimal time $\left(\mathrm{g} \mathrm{l}^{-1} \mathrm{~h}^{-1}\right)$;

$q_{\mathrm{LIE}}=\left(\mathrm{d}_{\mathrm{LIE}} / \mathrm{d} t\right) / x$,

where $\mathrm{d}_{\mathrm{LIE}} / \mathrm{d} t$ is the increase in the activity of LIE during infinitesimal time $\left(\mathrm{U}^{-1} \mathrm{~h}^{-1}\right)$.

\section{RESULTS}

\section{Isolation and morphological characterization of bld and whi mutants from S. exfoliatus SMF13}

Three bld and whi mutants were isolated from 10000 colonies of UV-treated spores of $S$. exfoliatus SMF13. The surface of the parent strain growing on Bennett agar or GCPS agar was tough and leathery. However, the surface of bld mutants was flat after $14 \mathrm{~d}$ growth and that of $w h i$ mutants was fluffy and whitish.

Scanning electron micrographs showed that the surface of colonies of the parent strain on GCPS agar consisted primarily of long rectiflexible spore chains, and that the surface of spores was smooth (Fig. 1a). However, the colony surface of bld mutants consisted of substrate hyphae embedded in agar medium, and lacked aerial mycelium and spores (Fig. 1b). The colony surface of $w h i$ mutants consisted of mycelia projecting upwards into the air (Fig. 1c).

The parent strain produced brown pigment in association with aerial mycelium formation; however, none of the bld mutants formed soluble pigments until $14 \mathrm{~d}$ growth. A spontaneous revertant to the wild-type phenotype obtained from bld mutant SMF13B1 during storage for several weeks at $4{ }^{\circ} \mathrm{C}$ sporulated like the parent strain and also regained pigment production.

\section{Physiological characteristics of b/d and whi mutants and the Spo ${ }^{+}$revertant}

In the surface culture of the parent strain (Fig. 2a), leupeptin was produced in association with the growth of substrate mycelium but it was inactivated by LIE, 

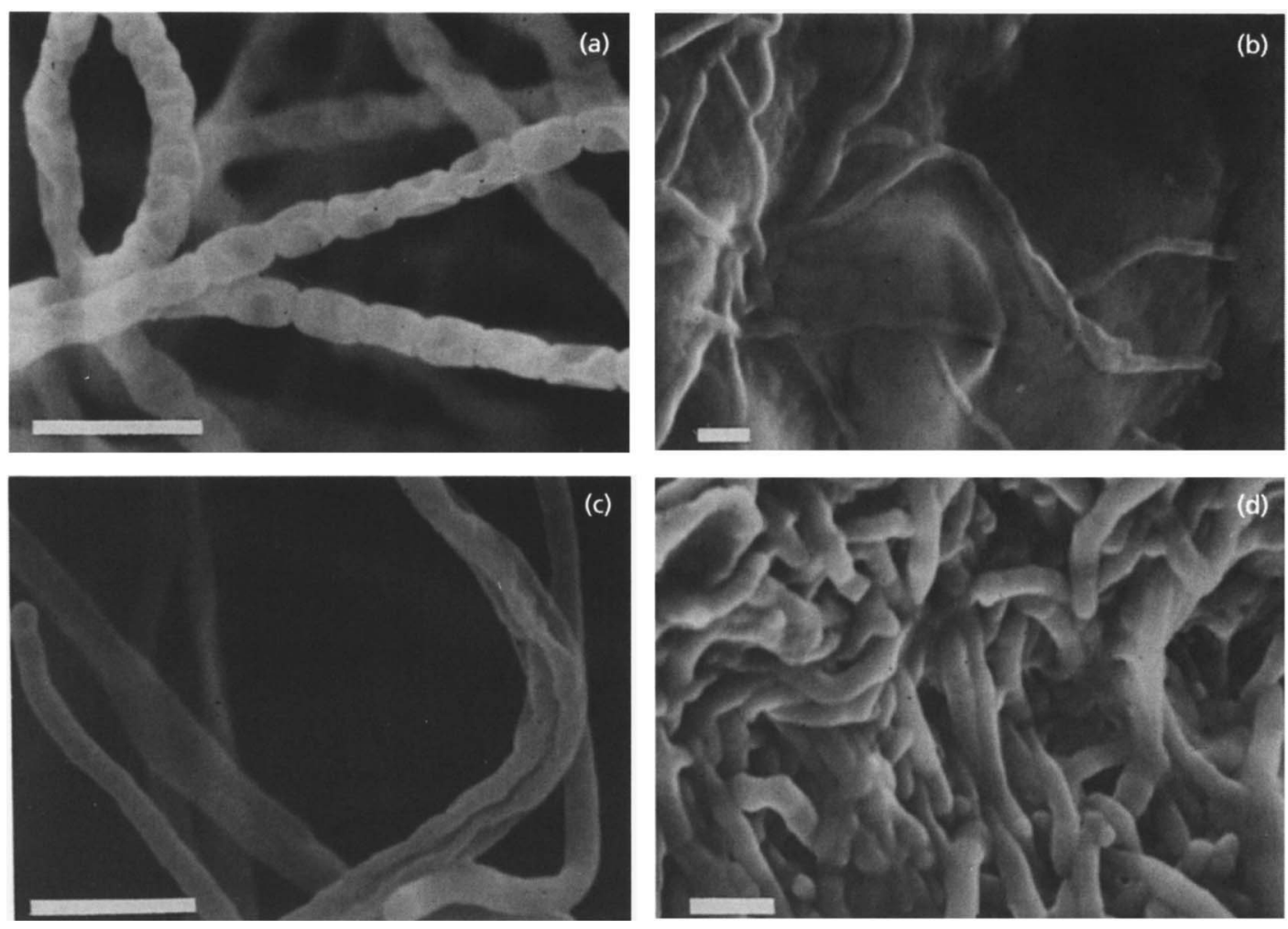

Fig. 1. Scanning electron micrographs of S. exfoliatus SMF13 (a), bld mutant SMF13B1 (b) and whi mutant SMF13W1 (c) on GCPS agar after $10 \mathrm{~d}$ incubation, and S. exfoliatus SMF13 (d) in GCPS agar supplemented with $2 \%$ glucose after $10 \mathrm{~d}$ incubation. Bars, $2 \mu \mathrm{m}$.

production of which began before aerial mycelium formed. Formation of aerial mycelium coincided with increases in the activities of LIE and TLP. However, in bld mutant SMF13B1 (Fig. 2b), leupeptin produced during the growth of substrate mycelium persisted throughout the culture, and neither LIE nor TLP was produced. Bald mutants SMF13B2 and SMF13B3 showed the same phenotype as SMF13B1. In wbi mutant SMF13W1 (Fig. 2c), leupeptin produced during substrate mycelium growth was inactivated by LIE, although the rates of leupeptin inactivation and of LIE production were lower than in the parent strain. When leupeptin was nearly inactivated, TLP activity emerged and aerial mycelium growth started. White mutant SMF13W2 showed the same phenotype as SMF13W1. The $\mathrm{Spo}^{+}$revertant SMF13R1 regained LIE and TLP production and showed the same pattern of morphological differentiation and production of LIE and TLP as the parent strain (Fig. 2d).

In a submerged batch culture of the parent strain (Fig. 3a), leupeptin produced during mycelium growth started to be degraded, in conjunction with the production of LIE, when glucose was nearly depleted and the mycelium growth rate declined. Moreover, TLP activity started to rise when leupeptin was nearly inactivated, coincident with a decrease in biomass concentration. In bld mutant SMF13B1 (Fig. 3b), the rate of leupeptin inactivation was much lower, and LIE and TLP activities were not detected. Moreover, mycelium autolysis was negligible. SMF13B2 and SMF13B3 showed the same phenotype as SMF13B1. In wbi mutant SMF13W1 (Fig. 3c), mycelium autolysis as well as production of LIE and TLP was retarded compared to the parent strain. SMF13W2 showed the same phenotype as SMF13W1, whereas $\mathrm{Spo}^{+}$ revertant SMF13R1 showed the same pattern of growth and production of LIE and TLP as the parent strain (data not shown).

Analysis of kinetic parameters for batch cultures showed very similar specific growth rates $(\mu)$, specific glucose uptake rates $\left(q_{\mathrm{s}}\right)$ and specific leupeptin production rates $\left(q_{\text {lpt }}\right)$ in the parent strain, bld mutants, whi mutants and $\mathrm{Spo}^{+}$revertant (Table 1 ). However, the specific mycelium degradation rates $\left(k_{\mathrm{d}}\right)$ in the parent strain and $\mathrm{Spo}^{+}$ revertant were much higher than those in wbi and bld mutants.

\section{Prevention of aerial mycelium formation and TLP production in the parent strain by glucose}

Addition of $2 \%$ glucose in the GCPS agar used for surface culture of the parent strain prevented the formation of both aerial mycelium and brown pigment. Scanning electron micrographs of colonies showed substrate mycelium without aerial mycelium and spores (Fig. 1d). Production of leupeptin increased with increasing 

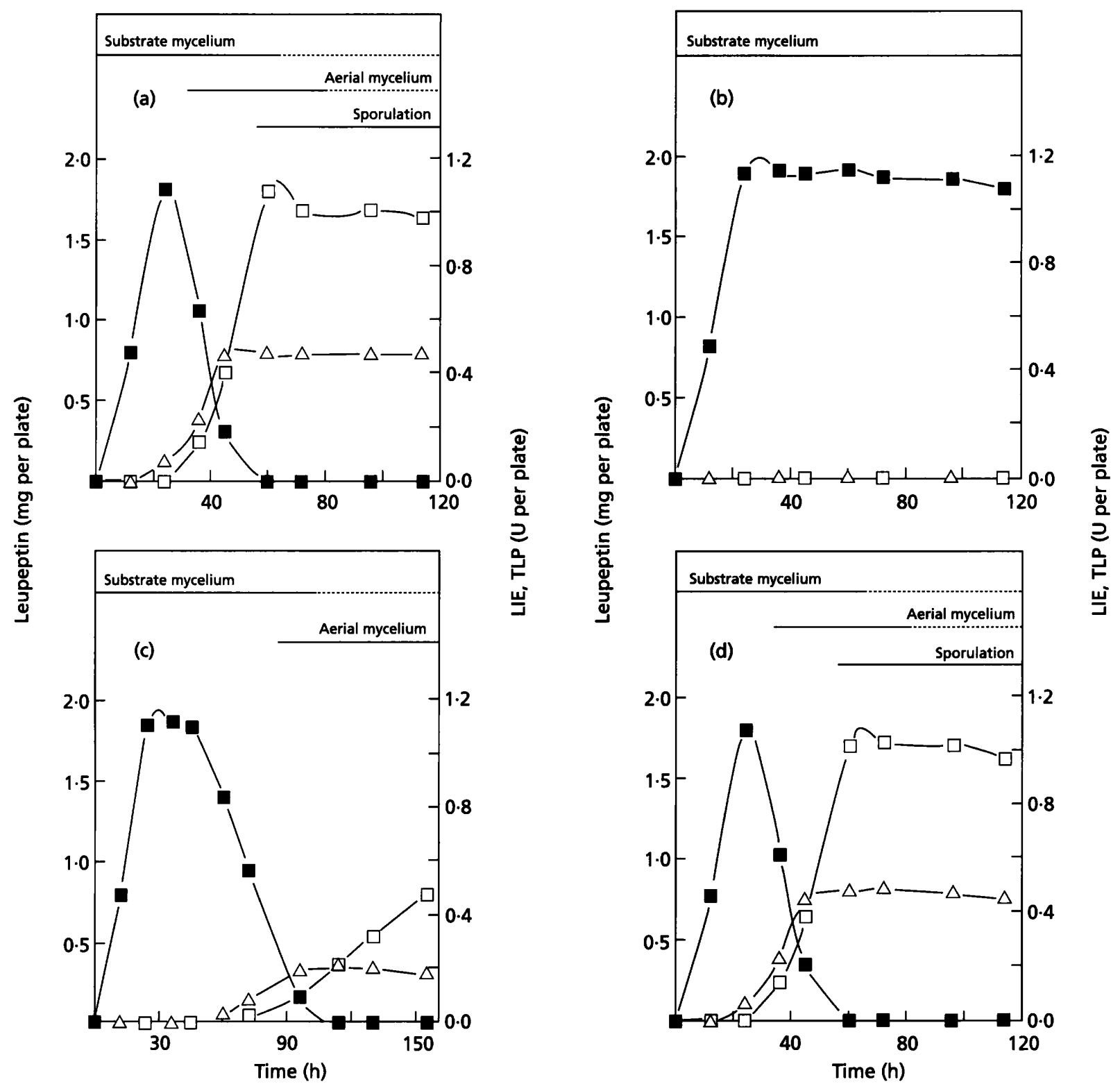

Fig. 2. Relationship between morphological differentiation of mycelium and production of leupeptin $(\square)$, LIE $(\triangle)$ and TLP ( $\square$ ) in surface cultures of S. exfoliatus SMF13 (a), bld mutant SMF13B1 (b), whi mutant SMF13W1 (c) and Spo revertant SMF13R1 (d). Cultures were grown on GCPS agar.

concentrations of glucose (Table 2). However, production of LIE and TLP decreased, and was completely absent at glucose concentrations above $2 \%$.

\section{Purification of trypsin-like protease, and determination of the $\mathrm{N}$-terminal amino acid sequence}

TLP was purified $47 \cdot 2$-fold with a recovery of $10 \cdot 2 \%$ (Table 3). The purified enzyme showed a single band by SDS-PAGE (Fig. 4a), and the molecular mass of the denatured protease was estimated to be $31.8 \mathrm{kDa}$. A zymogram of the purified protease showed a single band of activity, which was completely inhibited by treatment with leupeptin obtained from the same strain (Fig. 4b).
The $\mathrm{N}$-terminal amino acid sequence of the purified TLP was determined to be RVGGTxAAQGNFPFQQxLSM. The sequence showed $73 \%, 68 \%$ and $57 \%$ similarity to the N-terminal amino acid sequence of TLPs from Streptomyces griseus, Streptomyces fradiae and Streptomyces glaucescens, respectively (Fig. 5).

\section{Optimum reaction conditions and substrate specificity of the purified TLP}

The optimum $\mathrm{pH}$ and temperature for the hydrolysis of Hammarsten casein and a synthetic substrate (BAPNA) with TLP were 7.5 and $35^{\circ} \mathrm{C}$, respectively. Over $70 \%$ of the original activity was present after preincubation at 

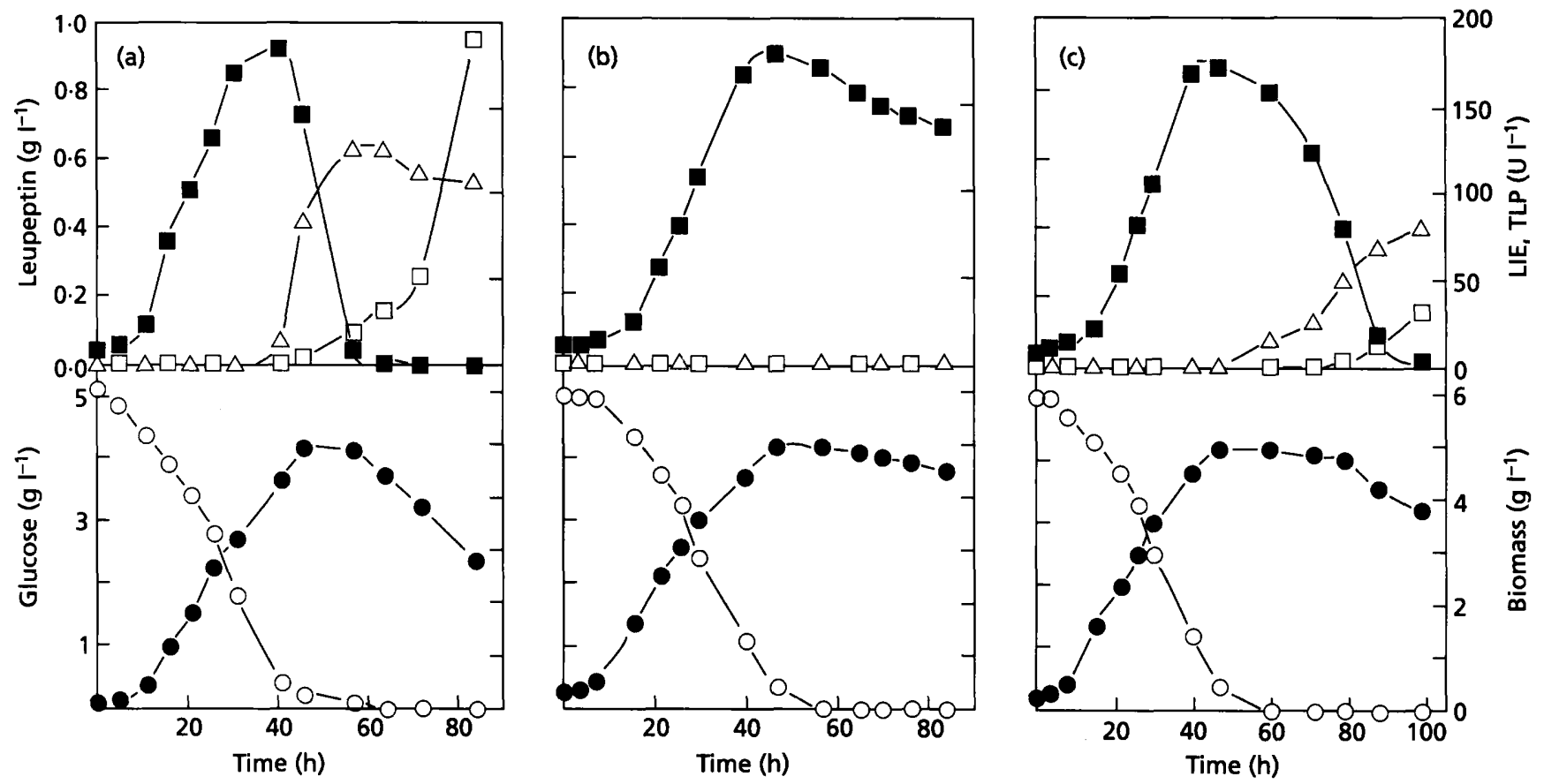

Fig. 3. Changes in the concentrations of biomass $(O)$, glucose $(O)$, leupeptin $(\square)$, LIE $(\triangle)$ and TLP ( $\square$ ) in submerged batch cultures of S. exfoliatus SMF13 (a), bld mutant SMF13B1 (b) and whi mutant SMF13W1 (c). Cultures were grown in GCPS medium.

Table 1. Kinetic parameters for batch cultures of $S$. exfoliatus SMF13, three bld mutants (SMF13B1, SMF13B2 and SMF13B3), two whi mutants (SMF13W1 and SMF13W2) and Spo+ revertant SMF13R1

\begin{tabular}{|c|c|c|c|c|c|c|c|}
\hline Kinetic parameters & SMF13 & SMF13B1 & SMF13B2 & SMF13B3 & SMF13W1 & SMF13W2 & SMF13R1 \\
\hline Specific growth rate $\left(\mu ; \mathrm{h}^{-1}\right)^{*}$ & 0.068 & 0.066 & $0 \cdot 067$ & 0.069 & 0.066 & 0.068 & 0.068 \\
\hline $\begin{array}{l}\text { Specific glucose uptake rate } \\
\left(q_{\mathrm{s}} ; \mathrm{g} \mathrm{g}^{-1} \mathrm{~h}^{-1}\right)^{*}\end{array}$ & $0 \cdot 062$ & 0.065 & 0.064 & $0 \cdot 063$ & $0 \cdot 064$ & 0.065 & $0 \cdot 065$ \\
\hline $\begin{array}{l}\text { Specific leupeptin production rate } \\
\left(q_{\mathrm{lpt}} ; \mathrm{g} \mathrm{g}^{-1} \mathrm{~h}^{-1}\right)^{*}\end{array}$ & $0 \cdot 014$ & $0 \cdot 014$ & $0 \cdot 015$ & $0 \cdot 014$ & $0 \cdot 015$ & $0 \cdot 015$ & $0 \cdot 015$ \\
\hline $\begin{array}{l}\text { Specific mycelium degradation rate } \\
\left(k_{\mathrm{d}} ; \mathrm{h}^{-1}\right) \dagger\end{array}$ & $0 \cdot 0185$ & 0.0021 & 0.0023 & $0 \cdot 0022$ & 0.0087 & 0.0085 & $0 \cdot 0184$ \\
\hline
\end{tabular}

* Maximum values calculated from data obtained during exponential growth.

$\dagger$ Mean values calculated from data obtained during death phase.

$30^{\circ} \mathrm{C}$ for $90 \mathrm{~min}$ in buffers between $\mathrm{pH} 3$ and $\mathrm{pH} 8$. However, the protease was unstable at a $\mathrm{pH}$ higher than 9 , and at temperatures above $40{ }^{\circ} \mathrm{C}$. More than $70 \%$ of the activity was lost by treatment at $40^{\circ} \mathrm{C}$ for $10 \mathrm{~min}$, and the activity was completely lost by treatment at $50^{\circ} \mathrm{C}$ for $10 \mathrm{~min}$.

TLP from $S$. exfoliatus SMF13 hydrolysed a broad range of native proteins such as bovine serum albumin, egg albumin, Hammarsten casein, collagen, haemoglobin and lysozyme (Table 4). The activity against casein and haemoglobin was greater than that against albumin, collagen and lysozyme. However, TLP obtained from S. exfoliatus SMF13 could not hydrolyse elastin. The $K_{\mathrm{m}}$ and $V_{\max }$ values obtained with Hammarsten casein as a substrate were $0.61 \mathrm{mg} \mathrm{m}^{-1}$ and 449.2 tyrosine equivalents $\min ^{-1} \mu \mathrm{M}^{-1}$, respectively.

Kinetic parameters for the hydrolysis of a number of synthetic aminoacyl $p$-nitroanilides by TLP are given in Table 5. The enzyme could hydrolyse various synthetic substrates for trypsin (aminoacyl $p$-nitroanilides containing arginine at the cleavage site). However, it could not hydrolyse chymotrypsin substrates such as $N$-benzoylTyr $p$-nitroanilide and $N$-succinyl-Gly-Gly-Phe $p$ nitroanilide. Moreover, TLP did not hydrolyse the synthetic elastase substrate $N$-succinyl-Ala-Ala-Ala $p$ nitroanilide. 
Table 2. Effect of glucose on aerial mycelium formation and production of leupeptin, LIE and TLP in surface cultures of $S$. exfoliatus SMF13

Spores from stock culture medium were used to inoculate GCPS agar containing increasing concentrations of glucose. Fifty agar plugs, each containing a colony, were pooled and analysed after $7 \mathrm{~d}$ culture. Concentrations of leupeptin, LIE and TLP were measured as described in Methods. ND, Not detected.

\begin{tabular}{|ccccc|}
\hline $\begin{array}{l}\text { Glucose } \\
(\%)\end{array}$ & $\begin{array}{c}\text { Aerial } \\
\text { mycelium } \\
(\%)\end{array}$ & $\begin{array}{c}\text { Leupeptin } \\
\text { ( } \boldsymbol{\mu g} \text { per } \\
\text { colony) }\end{array}$ & $\begin{array}{c}\text { LIE } \\
\text { (mU per } \\
\text { colony) }\end{array}$ & $\begin{array}{c}\text { TLP } \\
\text { (mU per } \\
\text { colony) }\end{array}$ \\
\hline 0.0 & 100 & 8.5 & $23 \cdot 4$ & $9 \cdot 8$ \\
$1 \cdot 0$ & 60 & $60 \cdot 8$ & $8 \cdot 3$ & 4.5 \\
$2 \cdot 0$ & 0 & 256.2 & $0 \cdot 4$ & ND \\
3.0 & 0 & $258 \cdot 4$ & 0.3 & ND \\
\hline
\end{tabular}

\section{Inhibitor specificity and inhibition kinetics}

The effect of protease inhibitors was determined using BAPNA as the substrate for purified TLP. Activity was completely inhibited by $50 \mu \mathrm{M}$ antipain or leupeptin (serine/cysteine protease inhibitor) and by $50 \mu \mathrm{M} \mathrm{N- \alpha -p-}$ tosyl-L-lysine chloromethyl ketone (TLCK) (trypsinspecific inhibitor). However, it was inhibited less than $15 \%$ by $50 \mu \mathrm{M}$ E-64 (cysteine protease inhibitor), pepstatin (aspartic protease inhibitor), L-1-tosylamide-2phenyl-ethyl chloromethyl ketone (chymotrypsin-specific inhibitor) and $1 \mathrm{mM}$ EDTA (metallo-protease inhibitor) (data not shown). TLP was competitively inhibited by leupeptin, the inhibition constant being $0.015 \mu \mathrm{M}$. The enzyme was also competitively inhibited by antipain, soybean trypsin inhibitor and TLCK; the inhibition constants were $0.534,0.029$ and $3.411 \mu \mathrm{M}$, respectively (data not shown).

TLP of $S$. exfoliatus SMF13 was not affected at a concentration of $10 \mathrm{mM}$ during a $1 \mathrm{~h}$ treatment by agents such as cysteine, dithiothreitol, glutathione and mercaptoethanol that break disulfide bonds in protein molecules. A $2 \mathrm{~h}$ treatment with $10 \mathrm{mM}$ mercaptoethanol reduced enzyme activity by only $15 \%$. The enzyme was also unaffected by iodoacetic acid, which modifies - $\mathrm{SH}$ groups in proteins. Like other bacterial trypsins, and unlike (a)

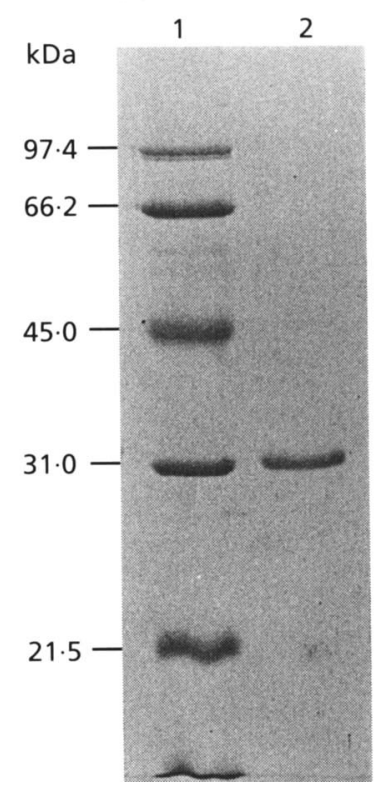

(b)

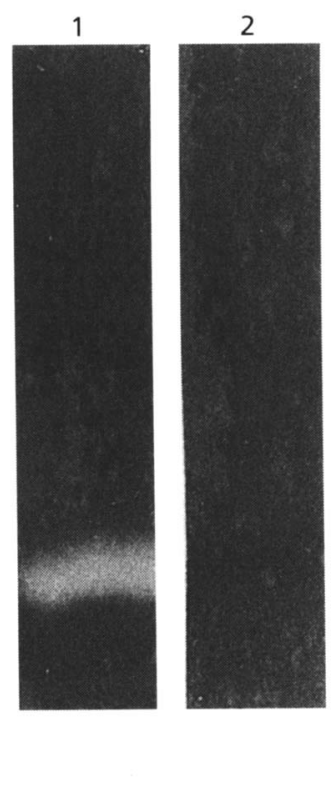

Fig. 4. SDS-PAGE (a) and substrate gel electrophoresis (b) of TLP purified from S. exfoliatus SMF13. (a) Lanes: 1, molecular mass standards; 2, purified TLP. (b) Zymogram of TLP obtained by $10 \%$ SDS-PAGE containing $0.1 \%$ gelatin. After electrophoresis, the gel was washed with $2.5 \%$ (v/v) Triton X-100 for $2 \mathrm{~h}$ to remove the SDS. The gel was incubated at $35^{\circ} \mathrm{C}$ for $4 \mathrm{~h}$ in $0.05 \mathrm{M} \mathrm{Tris} / \mathrm{HCl}$ buffer (pH 7.5) without (lane 1) or with (lane 2) $50 \mu \mathrm{M}$ leupeptin. After incubation, the gel was stained with Coomassie Blue.

mammalian trypsins, TLP from $S$. exfoliatus SMF13 was not activated by calcium ions (Keil, 1971). $\mathrm{Mg}^{2+}$ and $\mathrm{Mn}^{2+}$ did not affect the protease activity at a concentration of $5 \mathrm{mM}$, but $\mathrm{Cu}^{2+}, \mathrm{Hg}^{2+}$ and $\mathrm{Zn}^{2+}$ decreased the activity by more than $50 \%$.

\section{Degradation of mycelium protein by TLP}

Protein extracted from S. exfoliatus SMF13 mycelium was effectively hydrolysed by TLP (Fig. 6a), but the hydrolysis was completely inhibited by leupeptin (Fig. 6b). Although protease activities were apparently present in the mycelium, autodigestion of the mycelium extract was very

Table 3. Purification of TLP from S. exfoliatus SMF13

\begin{tabular}{|lccccc|}
\hline $\begin{array}{l}\text { Purification } \\
\text { step }\end{array}$ & $\begin{array}{c}\text { Protein } \\
\text { (mg) }\end{array}$ & $\begin{array}{c}\text { Activity } \\
\text { (U) }\end{array}$ & $\begin{array}{l}\text { Specific } \\
\text { activity } \\
\text { [U (mg } \\
\text { protein) }\end{array}$ & $\begin{array}{c}\text { Purification } \\
\text { (-fold) }\end{array}$ & $\begin{array}{c}\text { Yield } \\
\text { (\%) }\end{array}$ \\
\hline Culture broth & $1524 \cdot 0$ & 1555 & $1 \cdot 02$ & $1 \cdot 0$ & $100 \cdot 0$ \\
(NH $\left._{4}\right)_{2}$ SO $_{4}$ fractionation & $179 \cdot 7$ & 990 & $5 \cdot 51$ & $5 \cdot 4$ & $63 \cdot 7$ \\
pH adjustment to 3.6 & $75 \cdot 0$ & 780 & $10 \cdot 4$ & $10 \cdot 2$ & $50 \cdot 2$ \\
DEAE-Sephadex & $19 \cdot 9$ & 323 & $16 \cdot 2$ & $15 \cdot 9$ & $20 \cdot 8$ \\
Hydroxyapatite & $6 \cdot 47$ & 227 & $35 \cdot 1$ & $34 \cdot 4$ & $14 \cdot 6$ \\
CM-Sephadex & $3 \cdot 29$ & 159 & $48 \cdot 1$ & $47 \cdot 2$ & $10 \cdot 2$ \\
\hline
\end{tabular}




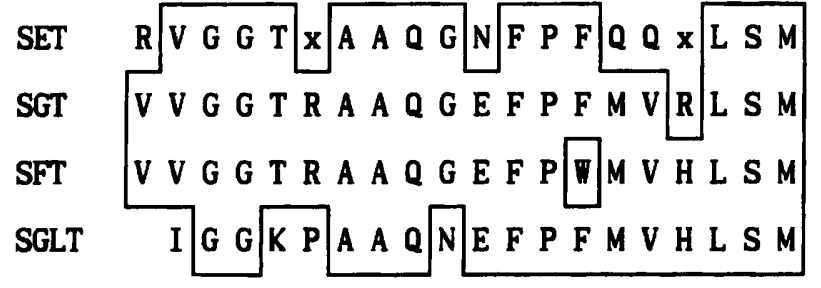

Fig. 5. Comparison of the $\mathrm{N}$-terminal amino acid sequence of TLP purified from $S$. exfoliatus SMF13 with those of other Streptomyces TLPs. SET, S. exfoliatus SMF13 TLP; SGT, S. griseus TLP (Olafson et al., 1975); SFT, S. fradiae TLP (N. Kikuchi and others, personal communication); SGLT, S. glaucescens TLP (G. Hintermann, personal communication). Identical amino acids are boxed; $x$ denotes an amino acid of uncertain identity.

Table 4. Hydrolysis of protein substrates by TLP purified from S. exfoliatus SMF13

The experimental conditions are given in Methods. After the reaction was complete, absorbance of trichloroacetic-acid-soluble material was measured at the wavelength specified. For albumin, Hammarsten casein, collagen, elastin, haemoglobin and lysozyme, 1 unit of activity was defined as the amount of TLP needed to produce $1 \mu \mathrm{g}$ tyrosine equivalent $\mathrm{min}^{-1}$. For azocasein, 1 unit of activity was defined as the amount of TLP needed to produce an absorbance increase of $0.001 \mathrm{~min}^{-1} \mathrm{~cm}^{-1}$.

\begin{tabular}{|lcc|}
\hline Substrate & $\begin{array}{c}\text { Wavelength } \\
\text { (nm) }\end{array}$ & $\begin{array}{c}\mathbf{U}(\boldsymbol{\mu g} \\
\text { protein) }\end{array}$ \\
\hline Azocasein & 440 & 3.23 \\
Hammarsten casein & 280 & 1.45 \\
Haemoglobin & 280 & 1.31 \\
Albumin (egg) & 280 & 0.50 \\
Albumin (bovine) & 280 & 0.44 \\
Collagen & 280 & 0.39 \\
Lysozyme & 280 & 0.17 \\
Elastin & 280 & 0.00 \\
Elastin Congo Red & 495 & 0.00 \\
\hline
\end{tabular}

slow (Fig. 6c). Chymotrypsin-like activity on $N$-benzoylTyr $p$-nitroanilide [specific activity $0.4556 \mathrm{mU}$ ( $\mu \mathrm{g}$ protein $)^{-1}$ ] was higher than trypsin-like activity on BAPNA [specific activity $0.008 \mathrm{mU}(\mu \mathrm{g} \text { protein })^{-1}$ ] in the mycelium protein.

\section{DISCUSSION}

Morphological differentiation in Streptomyces often coincides with the biosynthesis of pigment, antibiotics and certain extracellular enzymes (Babcock \& Kendrick, 1988; Chater, 1984; Martin \& Demain, 1980). bld mutants isolated from Streptomyces coelicolor and S. griseus were pleiotropically blocked in the biosynthesis of pigment and antibiotics (Babcock \& Kendrick, 1988; Champness, 1988; Daza et al., 1990; Merrick, 1976). All the bld mutants obtained from $S$. exfoliatus SMF13 during this study were pleiotropically blocked in the biosynthesis of
LIE and TLP, as well as in pigment production. In contrast, the Spo ${ }^{+}$revertant SMF13R1 regained the ability to produce pigment, LIE and TLP, and showed the same pattern of growth and production of LIE and TLP as the parent strain. This correlation between the bld phenotype, loss of LIE and TLP activities and loss of pigment production indicated that the phenomena could be controlled by the same mechanism. Because LIE and TLP were produced only in the strains producing aerial mycelium, such as the parent strain and whi mutants, these enzymes may have a role in aerial mycelium formation, but not in spore formation.

The physiological and morphological characteristics of the bld mutants were very similar to those reported for the parent strain grown with excess glucose (Kim \& Lee, 1995). Here also, morphological differentiation was completely repressed under conditions that prevented LIE and TLP synthesis. These results suggest a linkage between morphological differentiation and the production of LIE and TLP.

Extracellular proteases with the characteristics of TLP have been reported in many species of Streptomyces (Peczynska-Czoch \& Mordarski, 1988). That the activity is associated with differentiation is plausible, because the production of TLP in Streptomyces spp. coincides with the onset of aerial mycelium formation (Ginther, 1979; Gibb \& Strohl, 1988; Bascaran et al., 1990). Especially in $S$. exfoliatus SMF13, aerial mycelium formation was retarded by the external addition of leupeptin, and it resumed after inactivation of leupeptin by LIE (Kim \& Lee, 1995). Addition of TLCK, a specific inhibitor of TLP, to the top surface of colonies inhibited aerial mycelium formation in many streptomycetes, including $S$. aburaviensis, S. coelicolor, $S$. limosus, $S$. microflavus, $S$. roseus, $S$. albidoflavus, $S$. lavendulae, $S$. rochei, $S$. griseus, $S$. phaechromogenes, $S$. felleus and $S$. rimosus, and in S. exfoliatus SMF13 the inhibition persisted for at least $5 \mathrm{~d}$ (unpublished results). The long duration of TLCK inhibition could be attributed to complete inactivation of TLP by TLCK, which is stable under the conditions used.

The N-terminal amino acid sequence of TLP from $S$. exfoliatus is very similar to the $\mathrm{N}$-terminal sequences of TLPs from $S$. griseus, $S$. fradiae and $S$. glaucescens. In its $\mathrm{pH}$ optimum and thermal instability, the S. exfoliatus SMF13 enzyme also resembles TLPs from other Streptomyces. However, TLP from $S$. exfoliatus SMF13 was stable at $\mathrm{pH} 4 \cdot 5$, whereas the activity of other Streptomyces TLPs was lost at this $\mathrm{pH}$. The $K_{\mathrm{m}}(0.16 \mathrm{mM})$ of TLP from $S$. exfoliatus SMF13 for BAPNA was within the range of previously reported Streptomyces spp. values: $0.476 \mathrm{mM}$ for S. moderatus (Chandrasekaran \& Dhar, 1987), $0.029 \mathrm{mM}$ for $S$. paromomycinus (Chauvet et al., 1976), $0.101 \mathrm{mM}$ for S. griseus (Hatanaka et al., 1985), $0.328 \mathrm{mM}$ for $S$. rimosus (Renko et al., 1989) and $0.039 \mathrm{mM}$ for $S$. erythraeus (Yoshida et al., 1971). The $K_{\mathrm{m}}(0.0137 \mathrm{mM})$ of TLP from S. exfoliatus SMF13 for BAEE was also within the range of other Streptomyces TLPs: $0.152 \mathrm{mM}$ for $S$. moderatus (Chandrasekaran \& Dhar, 1987), $0.005 \mathrm{mM}$ for $S$. griseus (Hatanaka et al., 1985), 0.015 mM for $S$. fradiae (Morihara \& Tsuzuki, 1968), 0.182 mM for Streptomyces 
Table 5. Kinetic parameters for the hydrolysis of some peptidyl p-nitroanilides

Concentrations of the aminoacyl $p$-nitroanilides ranged from 2.5 to $1000 \mu \mathrm{M}$. The kinetic parameters were calculated from data obtained from reactions at concentrations of aminoacyl $p$-nitroanilides in the linear response range; NA, nitroanilide.

\begin{tabular}{|lccc|}
\hline Substrate & $\begin{array}{c}\boldsymbol{K}_{\mathbf{m}} \\
(\boldsymbol{\mu M})\end{array}$ & $\begin{array}{c}\boldsymbol{K}_{\text {cat }} \\
\left(\mathbf{s}^{-1}\right)\end{array}$ & $\begin{array}{c}\boldsymbol{K}_{\text {cat }} / \boldsymbol{K}_{\mathbf{m}} \\
\left(\mathbf{s}^{-1} \boldsymbol{\mu} \mathbf{M}^{-1}\right)\end{array}$ \\
\hline N-Benzoyl-Val-Gly-Arg $p$-NA & $35 \cdot 5$ & 181 & $5 \cdot 11$ \\
N-Benzoyl-Pro-Phe-Arg $p$-NA & $87 \cdot 5$ & 159 & $1 \cdot 82$ \\
N-Benzoyl-Val-Leu-Arg $p$-NA & 162 & 145 & $0 \cdot 89$ \\
N-Benzoyl-Phe-Val-Arg $p$-NA & 553 & 477 & $0 \cdot 86$ \\
N-Benzoyl-Ile-Glu-Gly-Arg $p$-NA & 1560 & 494 & $0 \cdot 32$ \\
N-Benzoyl-Arg $p$-NA & 160 & 27 & $0 \cdot 17$ \\
N-Benzoyl-Tyr $p$-NA & - & - & - \\
N-Succinyl-Gly-Gly-Phe $p$-NA & - & - & - \\
N-Succinyl-Ala-Ala-Ala $p$-NA & - & - & - \\
N-Succinyl-Ala-Ala-Val $p$-NA & - & - & - \\
N-Succinyl-Tyr-Leu-Val $p$-NA & - & - & - \\
\hline
\end{tabular}

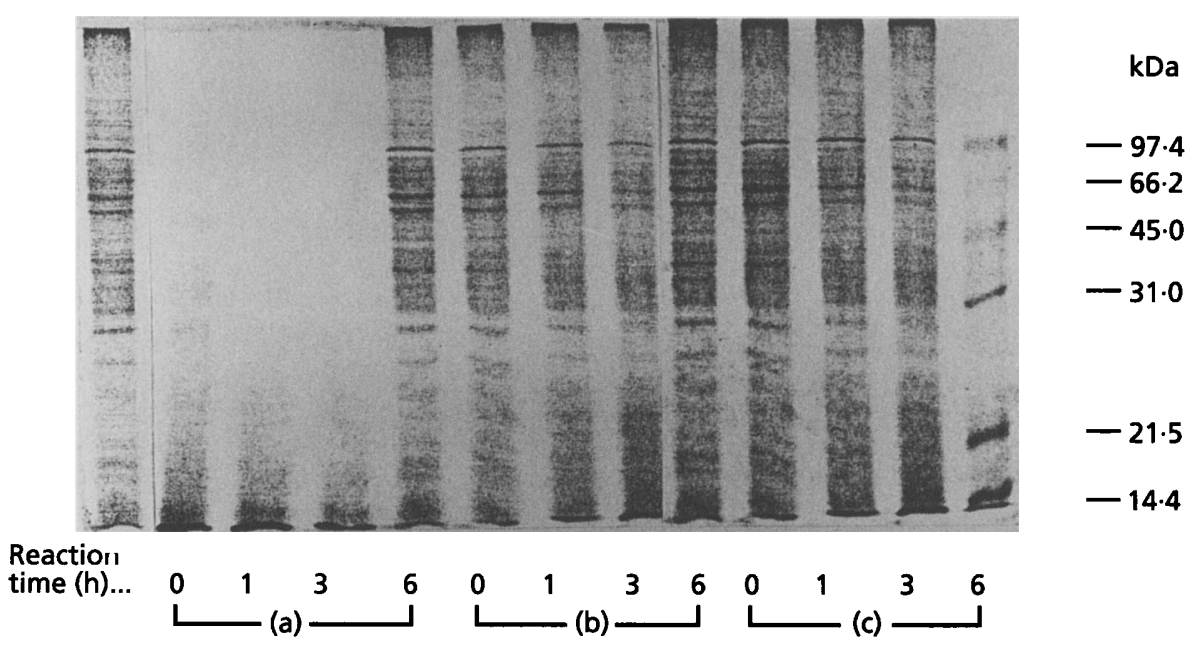

Fig. 6. Degradation of a mycelial protein extract of $S$. exfoliatus SMF13 by purified TLP. The enzyme $(5 \mu \mathrm{g})$ dissolved in $200 \mu \mathrm{l} \mathrm{Tris} / \mathrm{HCl}$ buffer $(\mathrm{pH} \mathrm{7.5,} 0.1 \mathrm{M})$ was preincubated at $35^{\circ} \mathrm{C}$ for $5 \mathrm{~min}$ without (a) or with (b) $10 \mu \mathrm{g}$ leupeptin. Mycelium protein extract $(2.8 \mathrm{mg})$ dissolved in $500 \mu \mathrm{l}$ Tris/ $\mathrm{HCl}$ buffer was added and the reaction mixture was incubated at $35^{\circ} \mathrm{C}$. Hydrolysis was measured by SDS-PAGE of the mycelial protein extract as a function of time. As a control, autodigestion of a mycelial protein extract was measured $(c)$.

771 (Palubinskas et al., 1984) and $0.018 \mathrm{mM}$ for $S$. erythraeus (Yoshida et al., 1971).

Our results are consistent with TLP and its autogenous inhibitor leupeptin having morphogenetic roles in $S$. exfoliatus SMF13. Mycelium protein extract was hydrolysed by TLP obtained from S. exfoliatus SMF13, and leupeptin clearly inhibited this hydrolysis. Moreover, the three bld mutants obtained by UV-mutagenesis were pleiotropically blocked in the biosynthesis of TLP, and mycelium autolysis in submerged cultures of these mutants was negligible compared with that in the parent strain. Since autoradiographic studies of colony development in Streptomyces have shown that substrate mycelium is metabolized to support aerial mycelium growth
(Mendez et al., 1985; Miguelez et al., 1994), we suggest that TLP digests substrate mycelium proteins in surface cultures (or non-growing mycelium proteins in submerged cultures) when the cultures are faced with nutrient limitation. Amino acids or oligopeptides liberated from the proteins by TLP support the growth of aerial mycelium on surface cultures or tip growth in submerged cultures; leupeptin protects growing substrate mycelium at the colony margins or growing tip mycelium from hydrolysis by TLP produced in growth-limited mycelium.

\section{ACKNOWLEDGEMENTS}

This work was supported by a research grant from the Research Centre for Molecular Microbiology (RCMM) supported by the Korea Science and Engineering Foundation (KOSEF). 


\section{REFERENCES}

Aoyagi, T. (1989). Protease inhibitor and biological control. In Bioactive Metabolites from Microorganisms: Progress in Industrial Microbiology, vol. 27, pp. 403-418. Edited by M. E. Bushell \& U. Grafe. New York: Elsevier.

Aoyagi, T., Miyata, S., Nanbo, M., Kojima, F., Matsuzaki, M., Ishizuka, M., Takeuchi, T. \& Umezawa, H. (1969). Biological activities of leupeptins. $\int$ Antibiot 22, 558-568.

Babcock, M. J. \& Kendrick, K. E. (1988). Cloning of DNA involved in sporulation of Streptomyces griseus. J Bacteriol 170, 2802-2808.

Bascaran, V., Hardisson, C. \& Brana, A. F. (1990). Regulation of extracellular protease production in Streptomyces clavuligerus. Appl Microbiol Biotechnol 34, 208-213.

Bradford, M. M. (1976). A rapid and sensitive method for the quantitation of microgram quantities of protein utilizing the principle of protein-dye binding. Anal Biochem 72, 248-254.

Champness, W. C. (1988). New loci required for Streptomyces coelicolor morphological and physiological differentiation. $J$ Bacteriol 170, 1168-1174.

Chandrasekaran, S. \& Dhar, S. C. (1987). Multiple proteases from Streptomyces moderatus. II. Isolation and purification of five extracellular proteases. Arch Biochem Biophys 257, 402-408.

Chater, K. F. (1984). Morphological and physiological differentiation in Streptomyces. In Microbial Development, pp. 89-115. Edited by R. Losick \& L. Shapiro. Cold Spring Harbor, NY : Cold Spring Harbor Laboratory.

Chauvet, J., Dostal, J. \& Acher, R. (1976). Isolation of a trypsin-like enzyme from Streptomyces paromomycinus (paromotrypsin) by affinity adsorption through kunitz inhibitor-sepharose. Int J Pept Protein Res 8, 45-55.

Daza, A., Martin, J. F. \& Gil, J. A. (1990). High transformation frequency of nonsporulating mutants of Streptomyces griseus. FEMS Microbiol Lett 71, 259-264.

Gibb, G. D. \& Strohl, W. R. (1988). Physiological regulation of protease activity in Streptomyces peucetius. Can J Microbiol 34, $187-190$.

Ginther, C. L. (1979). Sporulation and the production of serine protease and cephamycin C by Streptomyces lactamdurans. Antimicrob Agents Chemotber 15, 522-526.

Hatanaka, Y., Tsunematsu, H., Mizusaki, K. \& Makisumi, S. (1985). Interactions of derivatives of guanidinophenylalanine and guanidinophenylglycine with Streptomyces griseus trypsin. Biochim Biophys Acta 832, 274-279.

Hopwood, D. A., Bibb, M. J., Chater, K. F., Kieser, T., Bruton, C. J., Kieser, H. M., Lydiate, D. J., Smith, C. P., Ward, J. M. \& Schrempf, H. (1985). Mutagenesis of Streptomyces spores by ultraviolet light. In Genetic Manipulation of Streptomyces: a Laboratory Manual, pp. 37-38. Norwich: John Innes Foundation.

Keil, B. (1971). Trypsin. In The Enzymes, vol. 3, pp. 249-275. Edited by P. D. Boyer. New York, London: Academic Press.

Kim, I. S. \& Lee, K. J. (1995). Physiological roles of leupeptin and extracellular proteases in mycelium development of Streptomyces exfoliatus SMF13. Microbiology 141, 1017-1025.

Kim, I. S., Han, Y. T., Barrow, K. D. \& Lee, K. J. (1993). The structure of protease inhibitors produced by Streptomyces exfoliatus SMF13. Korean J Microbiol 31, 326-334.
Laemmli, U. K. (1970). Cleavage of structural proteins during the assembly of the head of bacteriophage T4. Nature 227, 680-685.

Martin, J.F. \& Demain, A. L. (1980). Control of antibiotic biosynthesis. Microbiol Rev 44, 230-251.

Matsudaira, P. (1987). Sequence from picomole quantities of proteins electroblotted onto polyvinylidene difluoride membranes. J Biol Chem 262, 10035-10038.

Mendez, C., Brana, A. F., Manzanal, M. B. \& Hardisson, C. (1985). Role of substrate mycelium in colony development in Streptomyces. Can J Microbiol 31, 446-450.

Merrick, M. J. (1976). A morphological and genetic mapping study of bald colony mutants of Streptomyces coelicolor. J Gen Microbiol 96, 299-315.

Miguelez, E. M., Garcia, M., Hardisson, C. \& Manzanal, M. B. (1994). Autoradiographic study of hyphal growth during aerial mycelium formation in Streptomyces antibioticus. J Bacteriol 176, 2105-2107.

Miller, G. L. (1959). Use of dinitrosalicylic acid reagent for determination of reducing sugar. Anal Chem 31, 426-428.

Millonig, G. (1961). Advantages of a phosphate of $\mathrm{OsO}_{4}$ solutions in fixation. J Appl Pbysiol 32, 1637-1640.

Morihara, K. \& Tsuzuki, H. (1968). A trypsin-like protease from Streptomyces fradiae. Arch Biochem Biophys 126, 971-973.

Narahashi, Y. (1970). Pronase. Methods Enzymol 19, 651-664.

Olafson, R. W., Jurasek, L., Carpenter, M. R. \& Smillie, L. B. (1975). Amino acid sequence of Streptomyces griseus trypsin. Cyanogen bromide fragments and complete sequence. Biochemistry 14, 1168-1176.

Palubinskas, V. I., Yankevich, N. B., Yanulaitene, K. K., Vesa, V. S., Bendikene, V. G., Maksimenko, A. V., Torchilin, M. P., llyina, E. V., Smirnov, V. N., Krestyanoe, L. N., Bartoshevich, Y. E. \& Zabirova, R. C. (1984). Trypsin-like enzyme from Streptomyces 771. Purification and properties of native and immobilized enzyme. Appl Biochem Biotechnol 9, 231-241.

Peczynska-Czoch, W. \& Mordarski, W. (1988). Actinomycete enzymes. In Actinomycetes in Biotechnology, pp. 246-250. Edited by M. Goodfellow, S. T. Williams \& M. Mordarski. London: Academic Press.

Pirt, S. J. (1975). Parameters of growth and analysis of growth data. In Principles of Microbe and Cell Cultivation, pp. 4-14. Oxford: Blackwell.

Renko, M., Vitale, L. J., Kokalj, M. \& Pokorny, M. (1989). Streptomyces rimosus extracellular proteases. 4. Trypsin-like proteinase. Appl Microbiol Biotechnol 31, 38-44.

Sarath, G., De La Motte, R. S. \& Wagner, F. W. (1989). Protease assay methods. In Proteolytic Enzymes: a Practical Approach, pp. 25-55. Edited by R. J. Beynone \& J. S. Bond. Oxford: IRL Press. Wildermath, H. (1970). Development and organization of the aerial mycelium in Streptomyces coelicolor. J Gen Microbiol 60, 43-50.

Yoshida, N., Sasaki, A. \& Inoue, H. (1971). An anionic trypsin-like enzyme from Streptomyces erytbraeus. FEBS Lett 15, 129-132.

Received 27 October 1995; revised 31 January 1996; accepted 13 February 1996. 